\title{
Fusibacter tunisiensis sp. nov., isolated from an anaerobic reactor used to treat olive-mill wastewater
}

\author{
Wajdi Ben Hania, ${ }^{1,2}$ Belkis Fraj, ${ }^{1,2}$ Anne Postec, ${ }^{1}$ Khaled Fadhlaoui, ${ }^{1}$ \\ Moktar Hamdi, ${ }^{2}$ Bernard Ollivier ${ }^{1}$ and Marie-Laure Fardeau ${ }^{1}$ \\ ${ }^{1}$ Laboratoire de Microbiologie M10, UMR 2359, Aix-Marseille Univ., Case 925, 163 Avenue de \\ Luminy, 13288 Marseille Cedex 9, France \\ ${ }^{2}$ Laboratoire d'Ecologie et de Technologie Microbienne, Institut National des Sciences Appliquées \\ et de Technologie, Centre Urbain Nord, BP 676, 1080 Tunis, Tunisia
}

Correspondence

Marie-Laure Fardeau

marie-laure.fardeau@univ-amu.fr

\begin{abstract}
Strain $B E L H 11^{\top}$, a novel mesophilic, anaerobic, halotolerant, rod-shaped bacterium, was isolated from a Tunisian wastewater digester. The cells of the strain are motile, measure $0.5 \times 2-5 \mu \mathrm{m}$, and occur singly or in pairs. The strain reduced thiosulfate and elemental sulfur (but not sulfate or sulfite) into sulfide. It grew at $15-40{ }^{\circ} \mathrm{C}$ (optimum $30{ }^{\circ} \mathrm{C}$ ), $\mathrm{pH} 5.8-8.4$ (optimum 7) and with 0$10 \%(\mathrm{w} / \mathrm{v}) \mathrm{NaCl}$ (optimum $3.0 \%$ ). The genomic DNA G $+\mathrm{C}$ content of strain $\mathrm{BELH}^{\top}{ }^{\top}$ was $38.2 \mathrm{~mol} \%$ and the strain's predominant cellular fatty acids were $\mathrm{C}_{14: 0}$, a summed feature that contained iso- $\mathrm{C}_{17: 1}$ and/or anteiso- $\mathrm{C}_{17: 1} \mathrm{~B}$, and $\mathrm{C}_{16: 0}$. Phylogenetic analysis based on $16 \mathrm{~S}$ rRNA gene sequences indicated that the novel strain was most closely related to Fusibacter paucivorans ( $94.8 \%$ sequence similarity). Based on phenotypic, phylogenetic and taxonomic characteristics, strain $B E L H 1{ }^{\top}$ represents a novel species of the genus Fusibacter, for which the name Fusibacter tunisiensis sp. nov. is proposed. The type strain is BELH1 ${ }^{\top}$ (=DSM $24436^{\top}=$ JCM $17481^{\top}$ ).
\end{abstract}

The genus Fusibacter, first proposed by Ravot et al. (1999), belongs to the phylum Firmicutes, order Clostridiales. To date, the genus contains only one recognized species, Fusibacter paucivorans, an anaerobic heterotrophic and thiosulfate-reducing bacterium isolated from a sample of reservoir water collected from an offshore oil-producing well in Congo, Central Africa (Ravot et al., 1999).

In the present study, a polyphasic approach was used for the taxonomic characterization of a novel mesophilic and halotolerant bacterium isolated from a digester used to treat wastewater from a Tunisian olive mill. The novel strain, which was able to use thiosulfate as a terminal electron acceptor, possessed phenotypic and phylogenetic traits that allowed its assignment as a novel species of the genus Fusibacter.

Samples were collected in Tunisia, from the sludge of a 2-litre anaerobic sequencing batch reactor, which was run at $35{ }^{\circ} \mathrm{C}$ and $\mathrm{pH} 7.5$, with a flow rate of $100 \mathrm{ml} \mathrm{day}^{-1}$, and fed with olive-mill wastewater $\left(100 \mathrm{ml} \mathrm{l}^{-1}\right)$ and phosphogypsum $\left(10 \mathrm{~g} \mathrm{l}^{-1}\right)$. The samples were collected under anaerobic conditions and transported to the research laboratory at ambient temperature. Strict anaerobic procedures

The GenBank/EMBL/DDBJ accession number for the 16S rRNA gene sequence of strain BELH1 ${ }^{\top}$ is FR851323. were followed for the microbial isolation and culture (Hungate, 1969).

The basal medium used for the isolation contained $\left(1^{-1}\right)$ : $1.0 \mathrm{~g} \mathrm{NH}_{4} \mathrm{Cl}, 0.3 \mathrm{~g} \mathrm{~K}_{2} \mathrm{HPO}_{4}, 0.3 \mathrm{~g} \mathrm{KH}_{2} \mathrm{PO}_{4}, 0.1 \mathrm{~g} \mathrm{KCl}$, $0.1 \mathrm{~g} \mathrm{CaCl}_{2} .2 \mathrm{H}_{2} \mathrm{O}, 23 \mathrm{~g} \mathrm{NaCl}, 1.0 \mathrm{~g}$ yeast extract (Difco), $1.0 \mathrm{~g}$ tryptone (Panreac Quimica), $0.5 \mathrm{~g}$ cysteine- $\mathrm{HCl}$, $1.6 \mathrm{~g} \mathrm{Na}_{2} \mathrm{~S}_{2} \mathrm{O}_{3}$ and $1 \mathrm{ml}$ Widdel trace element solution (Widdel \& Pfennig, 1982). The medium was adjusted to pH 7 with $10 \mathrm{M} \mathrm{KOH}$ solution before being boiled and cooled to room temperature under a stream of oxygenfree $\mathrm{N}_{2}$ gas. Aliquots of $5 \mathrm{ml}$ were dispensed into Hungate tubes, degassed under $\mathrm{N}_{2} / \mathrm{CO}_{2}(80: 20, \mathrm{v} / \mathrm{v})$ and then sterilized by autoclaving at $120{ }^{\circ} \mathrm{C}$ for $20 \mathrm{~min}$. Before inoculation with $0.5 \mathrm{ml}$ sample, the basal medium in each tube was supplemented with $0.1 \mathrm{ml} 10 \%(\mathrm{w} / \mathrm{v})$ $\mathrm{NaHCO}_{3}, 0.1 \mathrm{ml} 2 \%$ (w/v) $\mathrm{Na}_{2} \mathrm{~S} .9 \mathrm{H}_{2} \mathrm{O}, 0.1 \mathrm{ml} \mathrm{15 \%}$ (w/v) $\mathrm{MgCl}_{2} \cdot 6 \mathrm{H}_{2} \mathrm{O}$ and $0.1 \mathrm{ml} 1 \mathrm{M}$ glucose, all from sterile stock solutions.

Inoculated tubes were incubated at $30{ }^{\circ} \mathrm{C}$. Cultures were purified by repeated use of the Hungate roll-tube method (Hungate, 1969) and medium solidified with $1.6 \%(\mathrm{w} / \mathrm{v})$ agar, before transfer of each isolate back into liquid medium.

The $\mathrm{pH}$, temperature and $\mathrm{NaCl}$ concentration ranges for growth were determined using basal medium supplemented with $20 \mathrm{mM}$ glucose. Initial $\mathrm{pH}$ was varied, from 5.8 
to 8.4 , by injecting $0.1 \mathrm{M} \mathrm{HCl}, 10 \%$ (w/v) $\mathrm{NaHCO}_{3}$ or $8 \%(\mathrm{w} / \mathrm{v}) \mathrm{Na}_{2} \mathrm{CO}_{3}$ (each from a sterile anaerobic stock solution) into Hungate tubes that each contained $5 \mathrm{ml}$ medium. In other experiments, incubation temperatures were varied from $10{ }^{\circ} \mathrm{C}$ to $45^{\circ} \mathrm{C}$. For the tests of tolerance to $\mathrm{NaCl}$, the $\mathrm{NaCl}$ was added to dry Hungate tubes before the medium was dispensed into the tubes and autoclaved.

Cultures were subcultured into fresh medium at least twice, under the same experimental conditions, before determining growth rates and substrate use.

Gram staining was determined using heat-fixed liquid cultures and the Difco Gram staining kit, according to the manufacturer's instructions. The morphology of cells in the exponential phase of growth was investigated with an electron microscope (H600; Hitachi) at $75 \mathrm{kV}$, after negative staining with $1 \%(\mathrm{w} / \mathrm{v})$ sodium phosphotungstic acid (pH 7.0), as described by Fardeau et al. (1997).

Substrate utilization was tested by using basal medium containing the potential substrate at $20 \mathrm{mM}$ (arabinose, cellobiose, fructose, galactose, glucose, lactose, maltose, mannose, melibiose, raffinose, rhamnose, ribose, sorbitol, sorbose, sucrose, trehalose, xylose, formate, acetate, butyrate, lactate, propionate, Casamino acids, methanol and gelatin) or at $10 \mathrm{~g} \mathrm{l}^{-1}$ (tryptone). To test for electron acceptors, sodium thiosulfate $(20 \mathrm{mM})$, sodium sulfate $(20 \mathrm{mM})$, sodium sulfite $(2 \mathrm{mM})$ or elemental sulfur $\left(10 \mathrm{~g} \mathrm{l}^{-1}\right)$ were added to the medium. $\mathrm{H}_{2} \mathrm{~S}$ production was determined spectrophotometrically, as described by Cord-Ruwisch (1985). The end products of glucose metabolism were measured by HPLC, after incubation at $30{ }^{\circ} \mathrm{C}$ for 2 weeks (Fardeau et al., 1997).

Cultures of strain BELH1 ${ }^{\mathrm{T}}$ were stopped at the end of exponential phase and sent to the Deutsche Sammlung von Mikroorganismen und Zellkulturen (DSMZ), in Braunschweig, Germany, for fatty acid analysis. Fatty acids were extracted using the method of Miller (1982), with the modifications of Kuykendall et al. (1988), then separated on a gas chromatograph (6890N; Agilent Technologies) and identified using version 6.1 of the Sherlock Microbial Identification System (MIDI) and the TSBA40 database (Sasser, 1990).
The $\mathrm{G}+\mathrm{C}$ content of the genomic DNA of strain BELH1 ${ }^{\mathrm{T}}$ was also determined at the DSMZ; DNA was isolated and purified by chromatography on hydroxyapatite, using the procedure of Cashion et al. (1977), before the G+C content was determined by HPLC, as described by Mesbah et al. (1989).

The extraction and purification of total DNA from strain $B E L H 1^{\mathrm{T}}$, followed by the amplification and sequencing of the strain's 16S rRNA gene, were performed as described by Khelifi et al. (2010). The 16S rRNA gene sequence was then compared with sequences in the GenBank database by using a BLAST search (Altschul et al., 1990). A multiple sequence file was generated using version 5.0.9 of BioEdit (Hall, 1999). Alignments were made using the MUSCLE program (Edgar, 2004) before being manually refined using BioEdit. Phylogenetic trees were then constructed by using TREECON (Van de Peer \& De Wachter, 1994) and the neighbour-joining method with Kimura's two-parameter correction, the maximum-parsimony method, and the maximum-likelihood method (Felsenstein, 1981; Saitou \& Nei, 1987). Bootstrap values were based on 500 replications (Felsenstein, 1985).

In the initial isolation, the colonies seen in roll tubes were round and brown and measured about $2 \mathrm{~mm}$ in diameter after 12 days of incubation at $30{ }^{\circ} \mathrm{C}$. Serial dilution was repeated until each of the several isolates was deemed to be axenic. Three of the isolated strains, designated BELA1, BELB2 and BELH1 ${ }^{\mathrm{T}}$, were similar in morphology and phylogeny (99-100\% 16S rRNA gene sequence similarity) and produced the same end products from glucose metabolism. Strain $\mathrm{BELH}^{\mathrm{T}}$ was selected for further characterization.

The cells of strain BELH1 ${ }^{\mathrm{T}}$ were motile, Gram-stainingpositive rods that measured $0.5 \times 2-5 \mu \mathrm{m}$ and occurred singly or in pairs (Fig. 1a). Transmission electron microscopy of ultrathin sections revealed the typical cell wall of a Gram-positive bacterium, with an electron-dense layer (Fig. 1b). Spores were not observed.

Strain BELH1 ${ }^{\mathrm{T}}$ was anaerobic but tolerated up $1 \%(\mathrm{v} / \mathrm{v})$ $\mathrm{O}_{2}$. It was also mesophilic, growing at $15-40{ }^{\circ} \mathrm{C}$ (optimum $30{ }^{\circ} \mathrm{C}$ ) but not at $10{ }^{\circ} \mathrm{C}$ or $45{ }^{\circ} \mathrm{C}$. The strain grew with
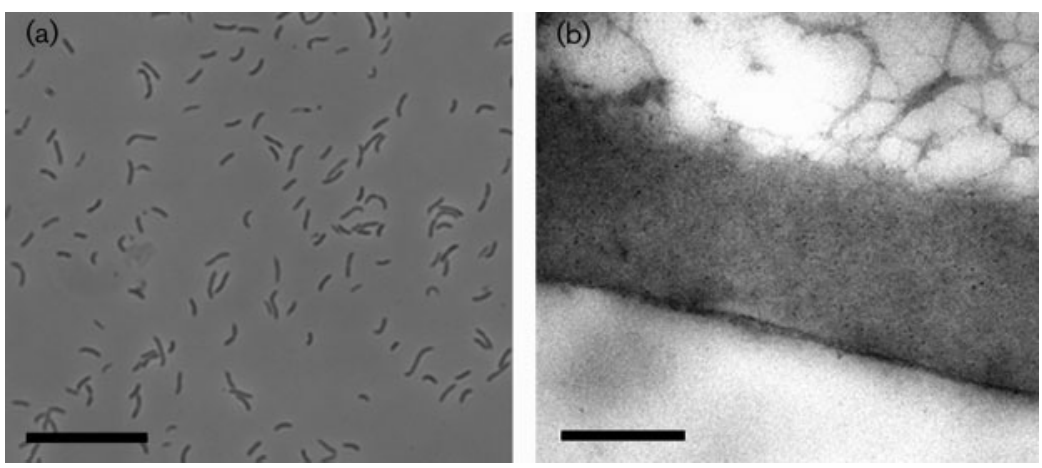

Fig. 1. (a) Phase-contrast photomicrograph showing cells of strain BELH1 ${ }^{\top}$. (b) Transmission electron micrograph of an ultrathin section of a cell of strain BELH $1^{\top}$, showing the Gram-positive-type of cell wall. Bars, $10 \mu \mathrm{m}$ (a) and $0.2 \mu \mathrm{m}$ (b). 


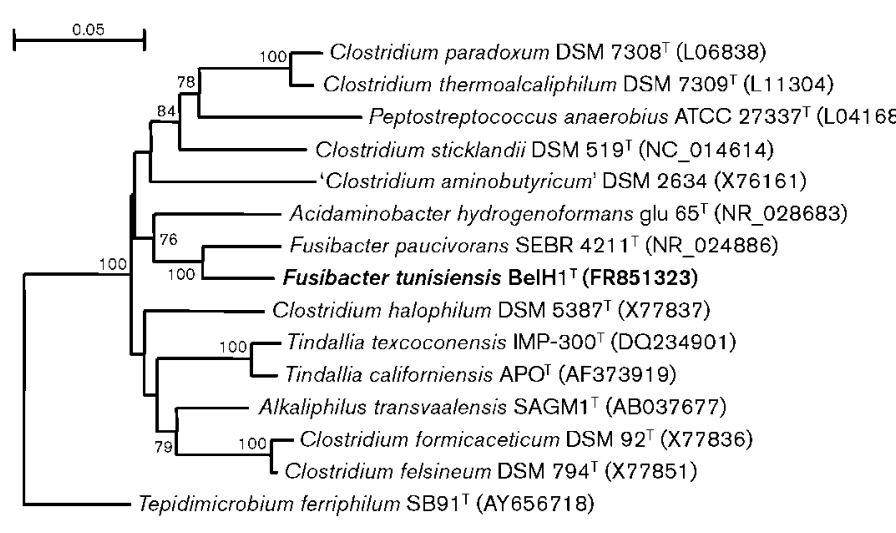

0-10\% (w/v) $\mathrm{NaCl}$ (optimum 3\%), and at pH 5.8-8.4 (optimum $\mathrm{pH}$ 7). Yeast extract was required for growth, and growth was enhanced in the presence of yeast extract and/or tryptone. Elemental sulfur and thiosulfate were used as terminal electron acceptors, but not sulfate or sulfite. Strain $\mathrm{BELH}^{\mathrm{T}}$ grew on glucose, maltose, sucrose and trehalose, both in the presence and absence of thiosulfate. Arabinose, cellobiose, fructose, galactose, lactose, mannose, rhamnose, ribose, sorbose, xylose, formate, acetate, lactate, propionate, Casamino acids, methanol, tryptone and gelatin were not utilized. The fermentation products detected in cultures grown on glucose were hydrogen, carbon dioxide and acetate, with a good carbon recovery. Thiosulfate reduction increased cellular yields and growth rates.

In the phylogenetic analysis, the amplified 16S rRNA gene sequence of strain $\mathrm{BELH1}^{\mathrm{T}}$ (1506 nt) was found to be most similar to the corresponding sequence of $F$. paucivorans SEBR $4211^{\mathrm{T}}(94.8 \%$ sequence similarity). Thus, in the neighbour-joining tree (Fig. 2), as in the maximum-parsimony and maximum-likelihood trees (data not shown), the novel strain was clustered with $F$. paucivorans.

Under identical growth conditions, biomass of both $F$. paucivorans SEBR $4211^{\mathrm{T}}$ and strain BELH1 ${ }^{\mathrm{T}}$ was obtained and used for fatty acid analysis. The results are shown in Table 1.

Strain BELH $1^{\mathrm{T}}$ could be differentiated from $F$. paucivorans by the range of substrates it could use, its fatty acid composition, its phylogeny, and its lower genomic DNA $\mathrm{G}+\mathrm{C}$ content (Table 2).

Based on the data obtained in this polyphasic study, strain $\mathrm{BELH}^{\mathrm{T}}$ represented a novel species of the genus Fusibacter, for which the name Fusibacter tunisiensis sp. nov. is proposed.

\section{Description of Fusibacter tunisiensis sp. nov.}

Fusibacter tunisiensis (tu.ni.si.en'sis. N.L. masc. adj. tunisiensis of or belonging to Tunisia, the country where the bacterium was first recovered).
Round colonies ( $1 \mathrm{~mm}$ in diameter) are present after incubation at $30{ }^{\circ} \mathrm{C}$ for 8 days. Cells are motile, measure $0.5 \times 2-5 \mu \mathrm{m}$ and appear singly or in pairs. Grows at $15-$ $40{ }^{\circ} \mathrm{C}$ (optimum $30{ }^{\circ} \mathrm{C}$ ) and at $\mathrm{pH} 5.8-8.4$ (optimum $\mathrm{pH}$ 7.0). Halotolerant, growing with $0-10 \%(\mathrm{w} / \mathrm{v}) \mathrm{NaCl}$ (optimum 3\%). Microaerophile. Utilizes glucose, maltose, sucrose and trehalose, but not arabinose, cellobiose, fructose, galactose, lactose, mannose, sorbose, rhamnose,

Table 1. Cellular fatty acid contents (\%) of strain BELH1 ${ }^{\top}$ and F. paucivorans SEBR $4211^{\top}$

Strains: $1, B E L H 11^{\mathrm{T}} ; 2$, F paucivorans SEBR $4211^{\mathrm{T}}$. - , Not detected.

\begin{tabular}{|lcc|}
\hline Fatty acid & $\mathbf{1}$ & $\mathbf{2}$ \\
\hline $\mathrm{C}_{10: 0}$ & 0.9 & - \\
$\mathrm{C}_{12: 0}$ & 9.1 & 1.9 \\
$\mathrm{C}_{13: 1}$ & 7.9 & 0.5 \\
$\mathrm{C}_{14: 0}$ & 30.4 & 8.3 \\
$\mathrm{Unknown} \mathrm{ECL}^{*} 14.959$ & 8.3 & 15.0 \\
$\mathrm{C}_{14: 1} \omega 5 c$ & - & 1.5 \\
$\mathrm{C}_{16: 0}$ & 9.3 & 6.3 \\
$\mathrm{C}_{16: 1} \omega 9 c$ & 3.4 & 10.7 \\
$\mathrm{C}_{16: 1} \omega 5 c$ & - & 0.6 \\
$\mathrm{Summed}$ features $\dagger$ & & \\
2 & 1.5 & - \\
3 & 2.7 & 12.5 \\
4 & 12.7 & 35.3 \\
iso- $_{19: 1} \mathrm{I}$ & - & 2.6 \\
$\mathrm{C}_{18: 0}$ & 1.1 & 0.9 \\
iso- $\mathrm{C}_{18: 1} \mathrm{H}$ & - & 0.5 \\
$\mathrm{C}_{18: 1} \omega 9 c$ & 1.4 & 1.4 \\
$\mathrm{C}_{18: 1} \omega 7 c$ & - & 1.0 \\
& & \\
\hline
\end{tabular}

*Equivalent chain-length.

$\dagger$ Summed features represent groups of two fatty acids that could not be separated by GLC with the MIDI system. Summed feature 2 contained $\mathrm{C}_{12: 0}$ ALDE?. Summed feature 3 contained $\mathrm{C}_{16: 1} \omega 7 \mathrm{c}$ and/ or iso- $\mathrm{C}_{15: 0} 2-\mathrm{OH}$. Summed feature 4 contained iso- $\mathrm{C}_{17: 1}$ and/or anteiso- $\mathrm{C}_{17: 1} \mathrm{~B}$. 
Table 2. Characteristics that differentiate strain $B E L H 1^{\top}$ from F. paucivorans

Strains: $1, \mathrm{BELH} 1^{\mathrm{T}} ; 2$, F. paucivorans SEBR $4211^{\mathrm{T}}$. +, Positive; - , negative.

\begin{tabular}{|lcc|}
\hline Characteristic & $\mathbf{1}$ & $\mathbf{2}$ \\
\hline Temperature for growth $\left({ }^{\circ} \mathrm{C}\right)$ & & \\
$\quad$ Range & $15-40$ & $20-45$ \\
Optimum & 30 & 37 \\
pH for growth & & \\
$\quad$ Range & $5.8-8.4$ & $5.7-8.0$ \\
Optimum & 7.0 & 7.3 \\
NaCl concentration for growth $(\%, \mathrm{w} / \mathrm{v})$ & & \\
Range & $0-10$ & $0-10$ \\
Optimum & 3 & $0-3$ \\
DNA G+C content $(\mathrm{mol} \%)$ & 38.2 & 43 \\
Substrates utilized: & & \\
Cellobiose & - & + \\
Fructose & - & + \\
Maltose & + & - \\
Ribose & - & + \\
Sucrose & + & - \\
Trehalose & + & - \\
\end{tabular}

ribose, xylose, acetate, lactate, propionate, Casamino acids, methanol, bio-Trypcase (bioMérieux) or gelatin. Requires yeast extract for growth. Reduces thiosulfate and elemental sulfur, but not sulfate or sulfite, into sulfide. The end products of glucose fermentation in the presence of yeast extract and tryptone are acetate, $\mathrm{CO}_{2}$ and $\mathrm{H}_{2}$. The major fatty acids are $\mathrm{C}_{14: 0}$, a summed feature that contained iso$\mathrm{C}_{17: 1}$ and/or anteiso- $\mathrm{C}_{17: 1} \mathrm{~B}$, and $\mathrm{C}_{16: 0}$.

The type strain, BELH1 ${ }^{\mathrm{T}}\left(=\right.$ DSM $\left.24436^{\mathrm{T}}=\mathrm{JCM} 17481^{\mathrm{T}}\right)$ was isolated in Tunisia from a digester treating olive-mill wastewater. The genomic DNA G $+\mathrm{C}$ content of the type strain is $38.2 \mathrm{~mol} \%$.

\section{Acknowledgements}

We thank Manon Joseph for help with the electronic microscopy and Dr P. Roger for revising the manuscript.

\section{References}

Altschul, S. F., Gish, W., Miller, W., Myers, E. W. \& Lipman, D. J. (1990). Basic local alignment search tool. J Mol Biol 215, 403-410.
Cashion, P., Holder-Franklin, M. A., McCully, J. \& Franklin, M. (1977). A rapid method for the base ratio determination of bacterial DNA. Anal Biochem 81, 461-466.

Cord-Ruwisch, R. (1985). A quick method for the determination of dissolved and precipitated sulfides in cultures of sulfate-reducing bacteria. J Microbiol Methods 4, 33-36.

Edgar, R. C. (2004). MUSCLE: multiple sequence alignment with high accuracy and high throughput. Nucleic Acids Res 32, 1792-1797.

Fardeau, M.-L., Ollivier, B., Patel, B. K. C., Magot, M., Thomas, P., Rimbault, A., Rocchiccioli, F. \& Garcia, J.-L. (1997). Thermotoga hypogea sp. nov., a xylanolytic, thermophilic bacterium from an oilproducing well. Int J Syst Bacteriol 47, 1013-1019.

Felsenstein, J. (1981). Evolutionary trees from DNA sequences: a maximum likelihood approach. J Mol Evol 17, 368-376.

Felsenstein, J. (1985). Confidence limits on phylogenies: an approach using the bootstrap. Evolution 39, 783-787.

Hall, T. A. (1999). BioEdit: a user-friendly biological sequence alignment editor and analysis program for Windows 95/98/NT. Nucleic Acids Symp Ser 41, 95-98.

Hungate, R. E. (1969). A roll tube method for the cultivation of strict anaerobes. Methods Microbiol 3B, 117-132.

Khelifi, N., Ben Romdhane, E., Hedi, A., Postec, A., Fardeau, M. L., Hamdi, M., Tholozan, J. L., Ollivier, B. \& Hirschler-Réa, A. (2010). Characterization of Microaerobacter geothermalis gen. nov., sp. nov., a novel microaerophilic, nitrate- and nitrite-reducing thermophilic bacterium isolated from a terrestrial hot spring in Tunisia. Extremophiles 14, 297-304.

Kuykendall, L. D., Roy, M. A., O’Neil, J. J. \& Devine, T. E. (1988). Fatty acids, antibiotic resistance, and desoxyribonucleic acid homology groups of Bradyrhizobium japonicum. Int J Syst Bacteriol 38, 358-361.

Mesbah, M., Premachandran, U. \& Whitman, W. B. (1989). Precise measurement of the $\mathrm{G}+\mathrm{C}$ content of deoxyribonucleic acid by highperformance liquid chromatography. Int J Syst Bacteriol 39, 159-167.

Miller, L. T. (1982). Single derivatization method for routine analysis of bacterial whole-cell fatty acid methyl esters, including hydroxy acids. J Clin Microbiol 16, 584-586.

Ravot, G., Magot, M., Fardeau, M.-L., Patel, B. K. C., Thomas, P., Garcia, J.-L. \& Ollivier, B. (1999). Fusibacter paucivorans gen. nov., sp. nov., an anaerobic, thiosulfate-reducing bacterium from an oilproducing well. Int J Syst Bacteriol 49, 1141-1147.

Saitou, N. \& Nei, M. (1987). The neighbor-joining method: a new method for reconstructing phylogenetic trees. Mol Biol Evol 4, 406-425.

Sasser, M. (1990). Identification of bacteria by gas chromatography of cellular fatty acids. USFCC Newsl 20, 16.

Van de Peer, Y. \& De Wachter, R. (1994). TREECON for Windows: a software package for the construction and drawing of evolutionary trees for the Microsoft Windows environment. Comput Appl Biosci 10, 569-570.

Widdel, F. \& Pfennig, N. (1982). Studies on dissimilatory sulphatereducing bacteria that decompose fatty acids II. Incomplete oxidation of propionate by Desulfobulbus propionicus gen. nov., sp. nov. Arch Microbiol 131, 360-365. 